POSTCOLONIAL DISORDERS 
This page intentionally left blank 


\section{POSTCOLONIAL DISORDERS}

Edited by

Mary-Jo DelVecchio Good,

Sandra Teresa Hyde,

Sarah Pinto, and

Byron J. Good

甲

University of California Press Berkeley Los Angeles London 
University of California Press, one of the most distinguished university presses in the United States, enriches lives around the world by advancing scholarship in the humanities, social sciences, and natural sciences. Its activities are supported by the UC Press Foundation and by philanthropic contributions from individuals and institutions. For more information, visit www.ucpress.edu.

University of California Press

Berkeley and Los Angeles, California

University of California Press, Ltd.

London, England

(C) 2008 by The Regents of the University of California

Library of Congress Cataloging-in-Publication Data

Postcolonial disorders / edited by Mary-Jo DelVecchio Good ... [et al.].

p. $\mathrm{cm}$.

Includes bibliographical references and index.

ISBN 978-0-520-25223-3 (cloth : alk. paper).ISBN 978-0-520-25224-0 (pbk. : alk. paper)

I. Medical anthropology. 2. Diseases-Social aspects. 3. Colonization-Social aspects. 4. Globalization-Social aspects. 5. Subjectivity. I. Good, Mary-Jo DelVecchio.

GN296.P67 2008

$306.4^{\prime} 6 \mathrm{I}-\mathrm{dc} 22$

2007029461

Manufactured in the United States of America

$\begin{array}{llllllllll}\text { I7 } & \text { I6 } & \text { I5 } & \text { I4 } & \text { I3 } & \text { I2 } & \text { II } & \text { IO } & 09 & 08\end{array}$

I0 $9 \begin{array}{lllllllll}10 & 8 & 7 & 6 & 5 & 4 & 3 & 2 & \text { I }\end{array}$

This book is printed on New Leaf EcoBook 50, a $100 \%$ recycled fiber of which $50 \%$ is de-inked post-consumer waste, processed chlorine-free. EcoBook 50 is acid-free and meets the minimum requirements of ANSI/ASTM D5634-OI (Permanence of Paper). 
Dedicated to Begoña Aretxaga (1960-2002) 
This page intentionally left blank 